\title{
A Methodology for Succession Planning for Technical Experts
}

Ron Cain

Carla Agreda Bernadette Kirk

May 2018 


\title{
DOCUMENT AVAILABILITY
}

Reports produced after January 1, 1996, are generally available free via US Department of Energy (DOE) SciTech Connect.

Website http://www.osti.gov/scitech/

Reports produced before January 1, 1996, may be purchased by members of the public from the following source:

\author{
National Technical Information Service \\ 5285 Port Royal Road \\ Springfield, VA 22161 \\ Telephone 703-605-6000 (1-800-553-6847) \\ TDD 703-487-4639 \\ Fax 703-605-6900 \\ E-mail info@ntis.gov \\ Website http://classic.ntis.gov/
}

Reports are available to DOE employees, DOE contractors, Energy Technology Data Exchange representatives, and International Nuclear Information System representatives from the following source:

Office of Scientific and Technical Information

PO Box 62

Oak Ridge, TN 37831

Telephone 865-576-8401

Fax 865-576-5728

E-mail reports@osti.gov

Website http://www.osti.gov/contact.html

This report was prepared as an account of work sponsored by an agency of the United States Government. Neither the United States Government nor any agency thereof, nor any of their employees, makes any warranty, express or implied, or assumes any legal liability or responsibility for the accuracy, completeness, or usefulness of any information, apparatus, product, or process disclosed, or represents that its use would not infringe privately owned rights. Reference herein to any specific commercial product, process, or service by trade name, trademark, manufacturer, or otherwise, does not necessarily constitute or imply its endorsement, recommendation, or favoring by the United States Government or any agency thereof. The views and opinions of authors expressed herein do not necessarily state or reflect those of the United States Government or any agency thereof. 
Nuclear Security and Isotope Technology Division

\title{
A METHODOLOGY for SUCCESSION PLANNING for TECHNICAL EXPERTS
}

\author{
Ron Cain \\ Carla Agreda \\ Bernadette Kirk ${ }^{1}$
}

Date Published: May 2018

\author{
Prepared by \\ OAK RIDGE NATIONAL LABORATORY \\ Oak Ridge, TN 37831-6283 \\ managed by \\ UT-BATTELLE, LLC \\ for the \\ US DEPARTMENT OF ENERGY \\ under contract DE-AC05-00OR22725
}

\footnotetext{
${ }^{1}$ Kirk Nuclear Information Services
} 



\section{CONTENTS}

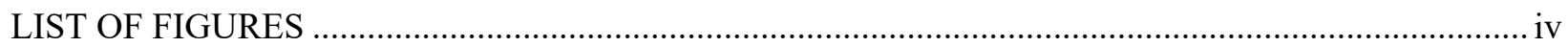

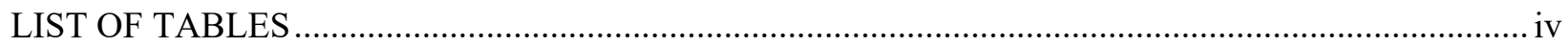

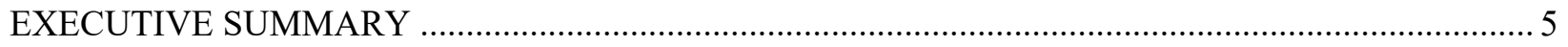

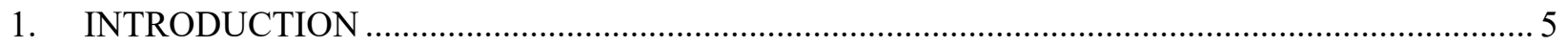

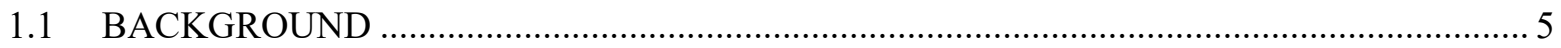

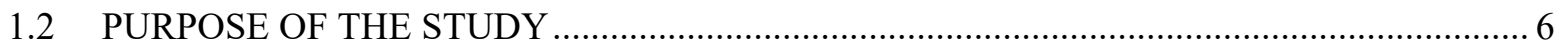

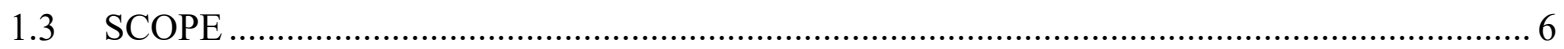

2. SUCCESSION PLANNING METHODOLOGY AND ANALYSIS …................................... 7

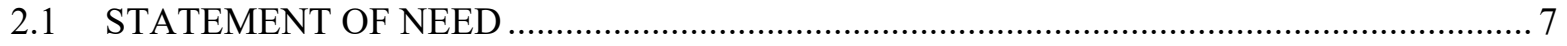

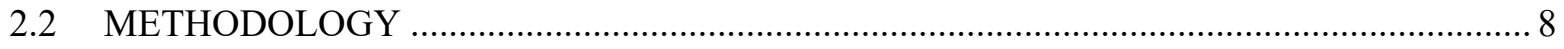

2.3 SUCCESSION PLANNING, KNOWLEDGE MANAGEMENT, AND MENTORSHIP ........ 9

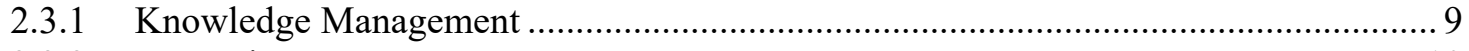

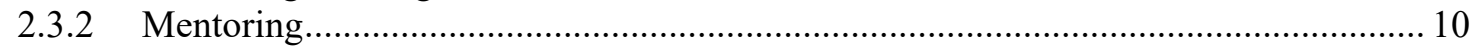

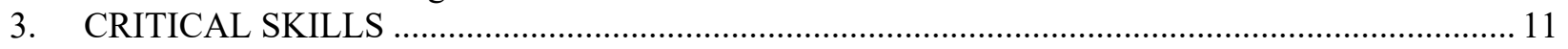

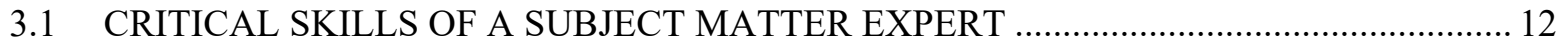

3.2 IDENTIFYING CRITICAL SKILLS IN A NUCLEAR FACILITY …................................ 12

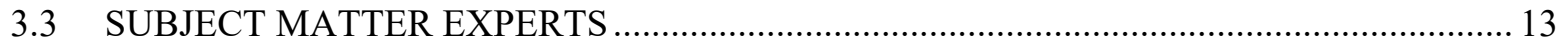

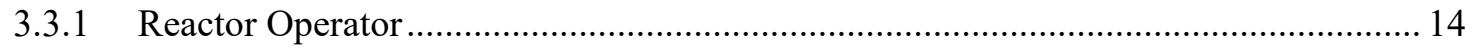

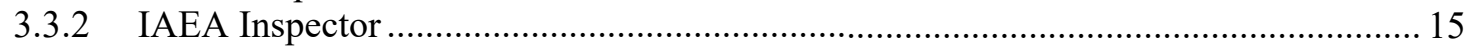

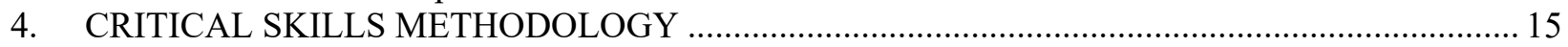

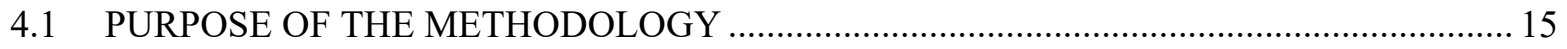

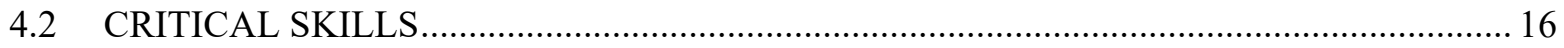

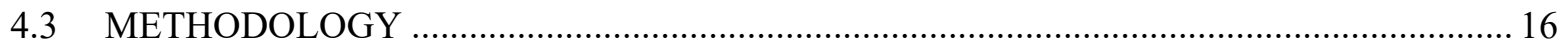

4.3.1 Select a Nuclear Facility or Expert Group of Individuals at a DOE National

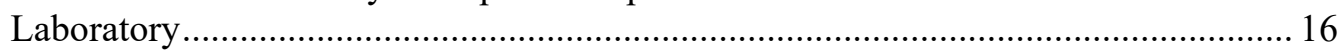

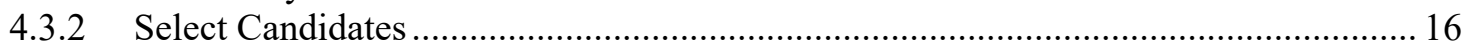

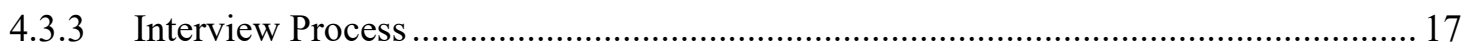

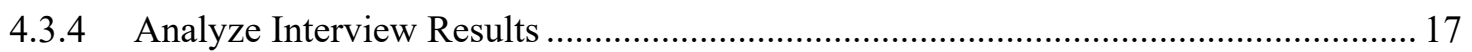

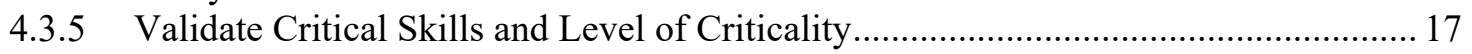

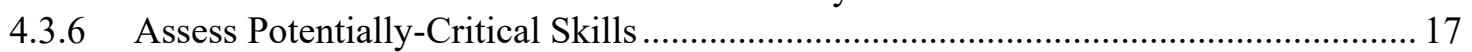

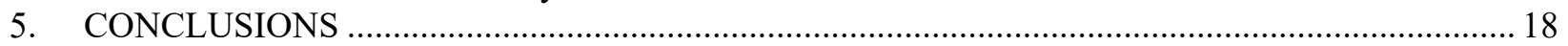

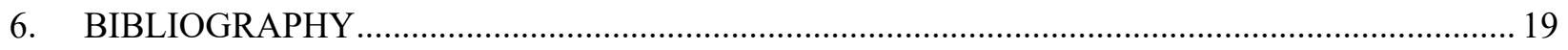

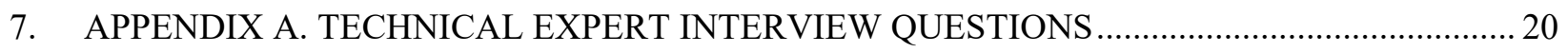




\section{LIST OF FIGURES}

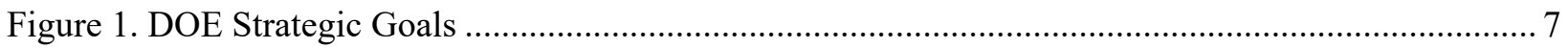

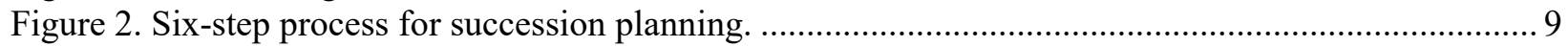

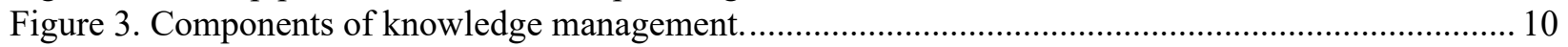

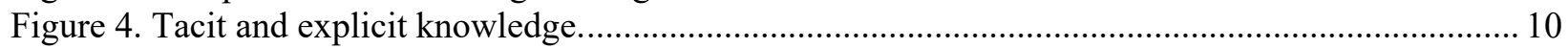

Figure 5. Tacit knowledge and mentoring in succession planning. ..................................................... 11

\section{LIST OF TABLES}

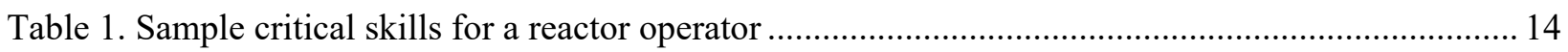

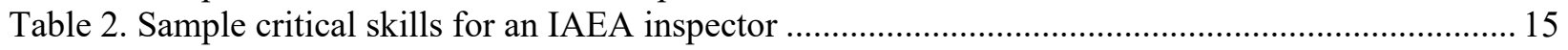

Table 3. Sample ranking of critical skills for a reactor operator .......................................................... 18 


\section{EXECUTIVE SUMMARY}

This report describes a methodology for identifying, evaluating, and mitigating the loss of key technical skills at nuclear operations facilities. The methodology can be adapted for application within regulatory authorities and research and development organizations and can be directly applied by international engagement partners of the Department of Energy's National Nuclear Security Administration (NNSA). The resultant product will be of direct benefit to two types of NNSA missions: (1) domestic human capital development programs tasked to provide focused technical expertise to succeed an aging nuclear operations workforce, and (2) international safeguards programs charged with maintaining operational safeguards for developing/maintaining nuclear power programs in nations where minimal available resources must be used effectively.

This report considers succession planning and the critical skills (also referred to as core competencies) necessary to meet an institution's goals and mission. Closely tied to succession planning are knowledge management and mentorship. In considering succession planning, critical skill sets are identified and are greatly dependent on the subject matter experts in question. This report also provides examples of critical skills that are job specific.

\section{INTRODUCTION}

\subsection{BACKGROUND}

Renewed international interest in developing nuclear power programs has resulted in an increased need for nuclear energy specialists worldwide. While this is good news for the nuclear power industry, a lack of growth during the previous three decades has resulted in a wide experience gap between those entering the field and those reaching retirement. Senior staff members who have remained part of the workforce possess knowledge and insight which they have gained over time. Until now, these highly-skilled and experienced personnel have not had access to a work base to which they could pass along their knowledge and valuable experiences. As these men and women retire, there is an unprecedented need to preserve and disseminate their knowledge base to a new generation of nuclear energy specialists.

The National Research Council's Committee on Assuring a Future US-Based Nuclear Chemistry Expertise stated, in a report ( National Research Council, 2012), that the growing use of nuclear medicine; the potential expansion of nuclear power generation; the need to protect the nation against external nuclear threats; the continued maintenance of the nuclear weapons stockpile; and the management of nuclear waste; all require a substantial, highly-trained, and exceptionally-talented workforce. To ensure that a long-term critical workforce's needs can be met, the committee recommends that "federal agencies should identify and prioritize urgent requirements for, and fund efforts for, knowledge transfer and retention." The committee also recommends a call for action in three main areas of need: (1) structural support and collaboration, (2) on-the-job training and knowledge transfer and retention, and (3) data collection and workforce tracking.

The International Atomic Energy Agency (IAEA) reported (IAEA, 2004) that in many Member States, nuclear safety, continued operation, and maintenance of nuclear reactors are becoming major challenges owing to the potential retirement of expert staff.

In its long-term research and development plan (IAEA, 2013), the IAEA states that the safeguards system needs to adapt to the growing number of nuclear power plants being built, since these plants will require increased uranium enrichment and reprocessing capabilities that are highly sensitive technologies. 
Expertise in these areas is much needed, and the current work force is not robust enough to face these challenges.

Therefore, to ensure the longevity of facilities and associated technology, there is an urgent need to address the transfer of nuclear knowledge from the current generation of workers to the next. Nuclear education and training must be continuous processes for generations to come, and succession planning should be addressed by nuclear facilities, not only at the management level, but also at the technical/subject matter expert level.

There is no question that a generation gap exists in the nuclear workforce. Baby Boomers, born between 1946 and 1964 who trained in nuclear science and technology and formed the foundation of the nuclear workforce for decades are now exiting this workforce en masse. Members of Generation X, born between 1965 and 1980, saw the rise of the nuclear industry, but 1978's Three Mile Island incident changed the industry landscape and had a negative impact on the public's perception of nuclear energy. As the US nuclear industry suffered the figurative fallout and loss of public support in the wake of the Three Mile Island debacle, government funding started to dwindle and with that came a decrease in the number of students in the university pipeline for nuclear engineering and related disciplines.

At the turn of the century, however, a nuclear renaissance began as US university enrollment in nuclear engineering saw an upward trend. Even with this renewed interest in nuclear technology among younger professionals entering the workforce, a 20-year gap still exists in the training of next-generation nuclear workers. Critical skills at nuclear facilities need to be retained and handed down to current and future members of the nuclear workforce. It is imperative that the US government be at the forefront to bridge this gap through a thoughtful and timely succession plan that incorporates knowledge management and mentoring.

\subsection{PURPOSE OF THE STUDY}

The purpose of the study is to address the lack of succession planning for technical experts in the Department of Energy (DOE) and other facilities worldwide. Knowledge is perishable. A large percentage of experienced research and operational staff is nearing retirement age just as the need for their involvement is increasing. Those who have not yet left the workforce can be expected to do so soon. Actions must be taken quickly if DOE is to protect its investment in nuclear technology leadership.

To address the lack of succession planning for technical experts, the report aims to create a methodology whereby critical skill sets are identified so an organization can identify positions that require attention. This methodology can be incorporated into existing processes for succession planning. Most organizations currently do succession planning for management positions and this methodology can provide data for succession planning for technical experts.

\subsection{SCOPE}

The study outlined in this report focuses on succession planning and its components with the goal of developing a methodology that can identify unique skills that an individual may possess and evaluate those unique skills against an objective metrics to determine if they are critical to the organization and if they should be retained and propagated to additional personnel. The report also touches on knowledge management and mentoring and their importance in succession planning.

The report is organized as follows. Section 2 provides the background, purpose of the study, and scope of the report. Section 3 discusses the succession planning methodology and analysis and includes the statement of need; a discussion on knowledge management and mentoring is also presented, followed by 
a description of critical skills. Section 4 provides the methodology used in the identification of critical skills. Section 5 provides the conclusions of the study. To avoid reinventing the wheel, Sections $2-4$ draw heavily on several sources that represent the nuclear industry's best practices.

\section{SUCCESSION PLANNING METHODOLOGY AND ANALYSIS}

\subsection{STATEMENT OF NEED}

DOE's mission is to enhance security and economic growth in the United States through transformative science, technology innovation, and market solutions that meet the energy, nuclear security, and environmental challenges that face the United States ( Department of Energy, 2016). As shown in Figure 1, DOE has three primary strategic goals: (1) science and energy, (2) nuclear security, and (3) management and performance. To accomplish these goals, DOE and its national laboratories must maintain a fully-engaged workforce with requisite skills and experience through careful planning, improved outreach, and recruitment programs.

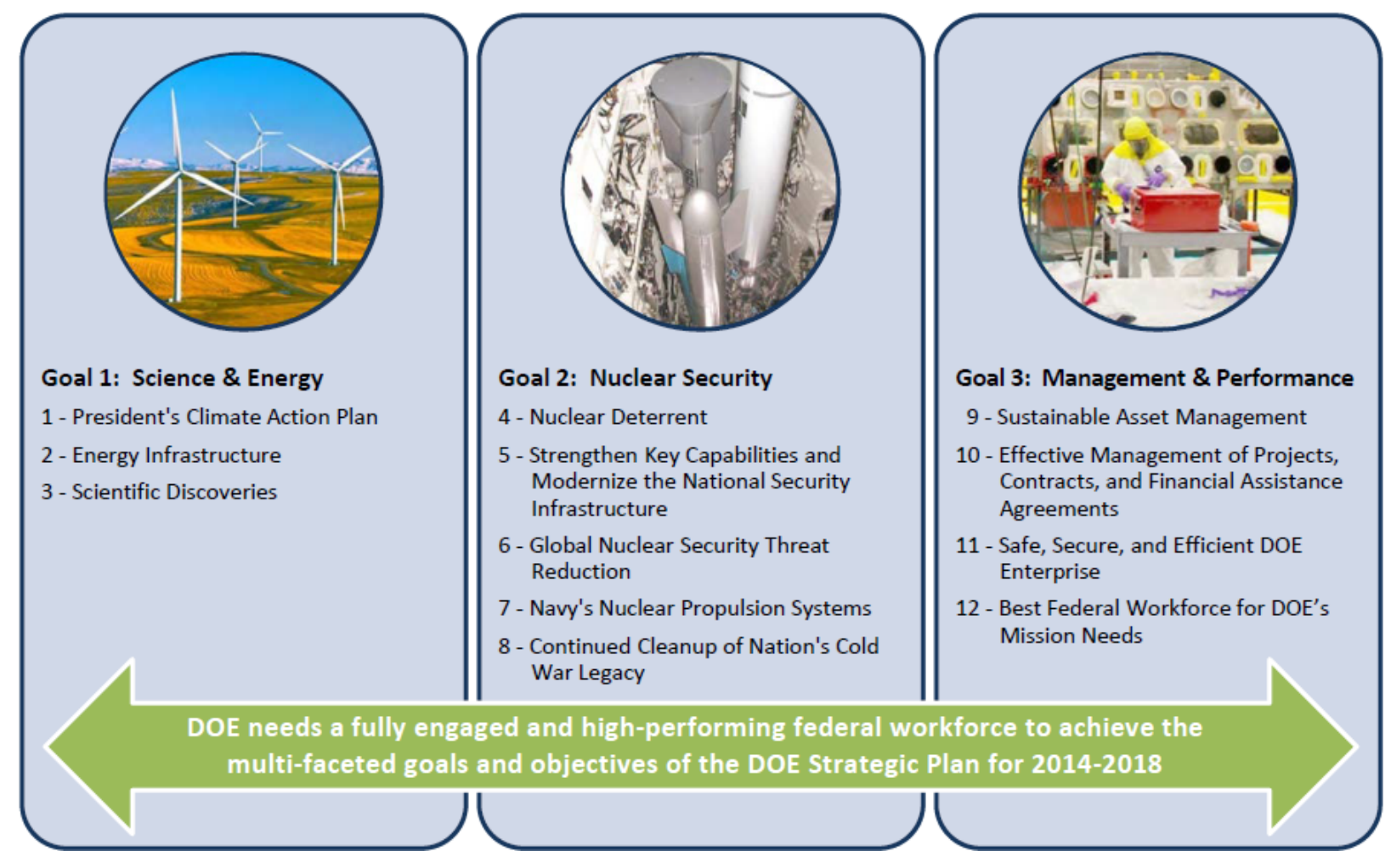

Figure 1. DOE Strategic Goals ${ }^{2}$

A study by the Oak Ridge Institute of Science Education (ORISE) (ORISE, 2009) painted a bleak picture of the nuclear safeguards workforce at the national laboratories. The study which was funded by the NNSA's program "Next Generation Safeguards Initiative" (NGSI), found that, over the span of 15 years, if no efforts are made to train the next generation of potential safeguards experts, the number of key personnel will dwindle to about $1 / 5$ of the 2009 workforce.

In a presentation to the US Office of Personnel Management (OPM), Timothy Lagan stated that significant attention has been placed on succession planning for leadership positions in government

${ }^{2}$ Adapted from ( Department of Energy, 2016) 
agencies, but that less emphasis has been placed on mission-critical, professional-level positions (Timothy Lagan, 2005). This observation was based on workforce analysis research that Lagan conducted to identify and mitigate employee skill gaps in government agencies.

With the skill and expertise requirements for fulfilling DOE's strategic mission at odds with the stark assessment provided in the ORISE study, a closer look at the lack of succession planning for technical experts requires urgent attention.

\subsection{METHODOLOGY}

Succession planning is a systematic approach to (US Office of Personnel Management, 2005):

- building a pipeline to ensure project continuity;

- developing potential successors in ways that best fit their strengths;

- identifying the best candidates for the positions; and

- concentrating resources on the talent development process to yield a greater return on investment.

Succession planning is closely tied to an organization's mission and vision. Succession planning identifies key staff positions, risk of losing an incumbent, potential succession candidates, and developmental activities and assignments for the successor.

The primary elements of succession planning involve, but are not limited to, mission critical occupations and their competencies; current workforce, including anticipated retirements and separations; current skills and competencies of the workforce; future demand of mission-critical occupations; and gap analysis to evaluate the gap between the supply and demand.

According to OPM, the six steps for effective succession planning are: (1) link strategic and workforce planning; (2) analyze gaps; (3) identify talent pools; (4) develop succession strategies; (5) implement succession strategies; and (6) monitor and evaluate. These steps are illustrated in (Figure 2). 


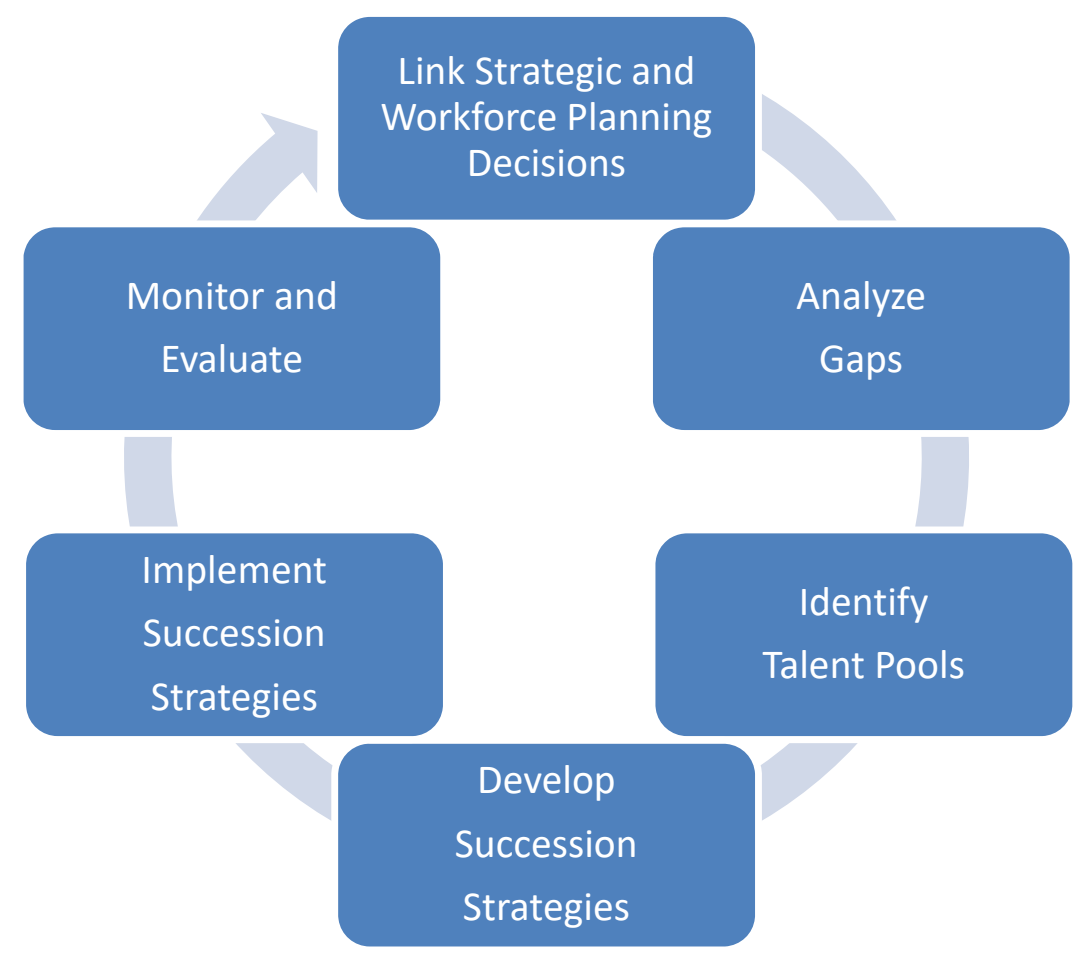

Figure 2. Six-step process for succession planning.

\subsection{SUCCESSION PLANNING, KNOWLEDGE MANAGEMENT, AND MENTORSHIP}

According to the IAEA (IAEA Nuclear Energy Series, 2011), nuclear knowledge management is "an integrated, systematic approach applied to all stages of the nuclear knowledge cycle, including identification, sharing, protection, dissemination, preservation and transfer." The IAEA strongly recommends that emphasis be placed on knowledge management, workforce planning, recruitment initiatives, training programs, and succession planning (IAEA, 2006).

\subsubsection{Knowledge Management}

Succession planning uses the 4-R paradigm of knowledge management (Shaheen Dewji, 2015). These paradigms are retention, retirement, recruitment, and resources (Figure 3). 


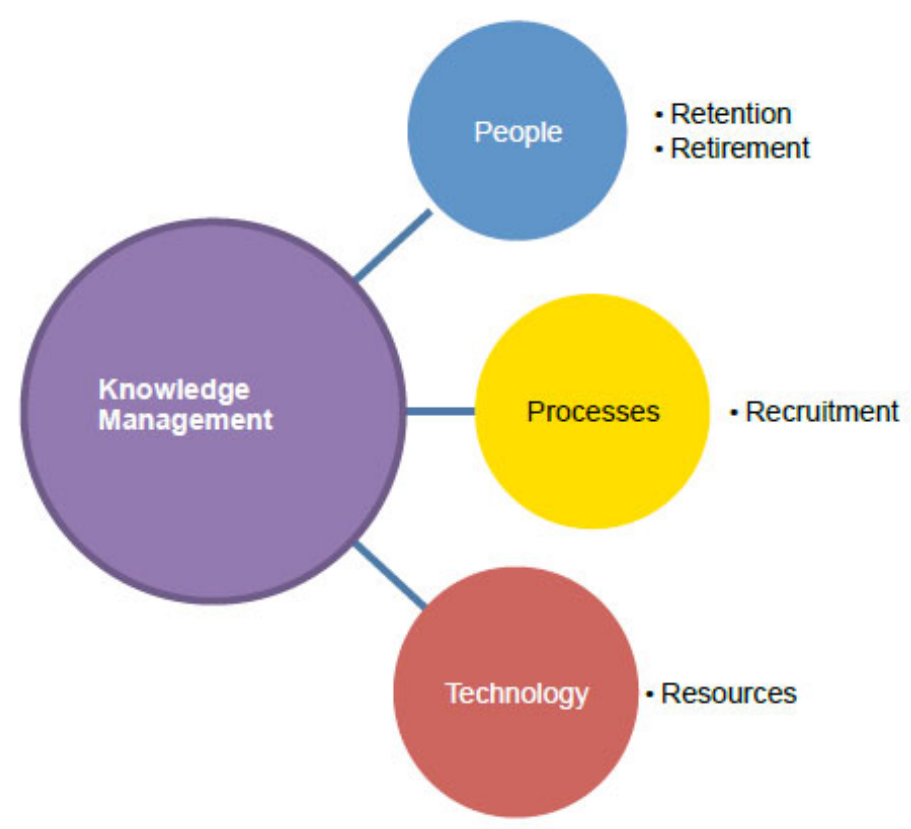

Figure 3. Components of knowledge management. ${ }^{3}$

Within any organization, retention, retirement, and recruitment are the primary foci of strategic workforce planning. Retirement is currently a major factor impeding efforts to ensure a sustainable nuclear workforce as aging technical experts with years of knowledge and experience leave the nuclear industry in droves. The IAEA identifies two forms of knowledge: (1) tacit or implicit and (2) explicit (IAEA Nuclear Energy Series, 2011). Tacit knowledge resides in individuals, whereas explicit knowledge is one that has been captured in documents, databases, and literature as illustrated in (Figure 4).
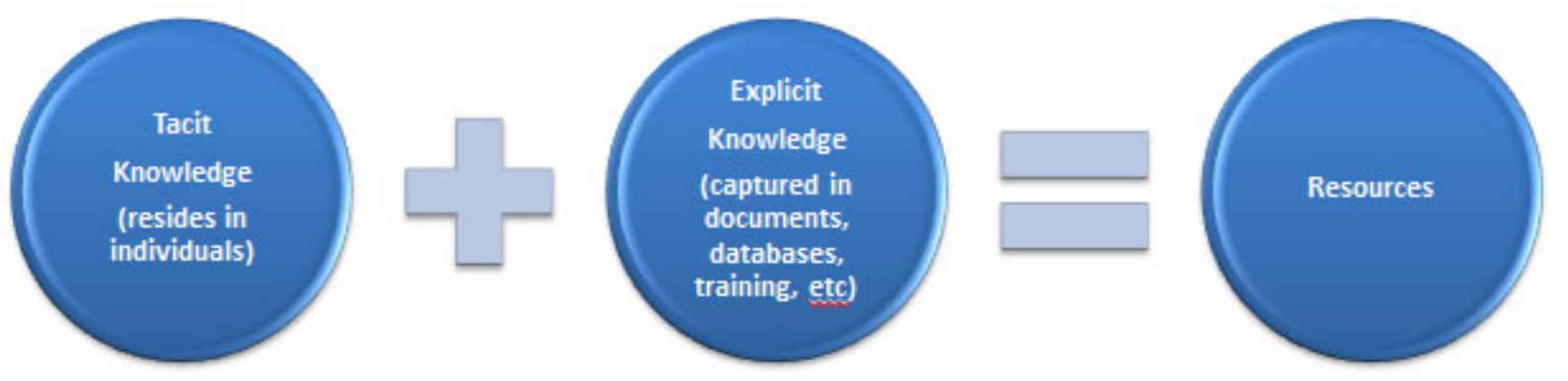

Figure 4. Tacit and explicit knowledge.

Following OPM's model, the US Nuclear Regulatory Commission (NRC, 2012) successfully launched a knowledge management program with strategic workforce planning. Because of its efforts to hire and retain a highly-skilled and motivated workforce using knowledge management processes, the NRC was ranked as the top government employer in both 2007 and 2009.

\subsubsection{Mentoring}

Explicit and tacit knowledge helps in identifying critical skills which are closely tied to an organization's mission. Explicit nuclear knowledge is readily available, whereas tacit nuclear knowledge is more difficult to quantify and extract. A technical expert's breadth of knowledge, gained over the span of years

3. Adapted from (Shaheen Dewji, 2015) 
or even decades, cannot be captured by simply researching literature. This dissemination gap is where a mentoring program becomes crucial. Strategic skills can be handed down from a mentor to a mentee through a strong networking environment.

The relationship between tacit knowledge, mentoring, and succession planning is illustrated in 5 . As always, the organization's strategic mission and goals drive the processes involved.

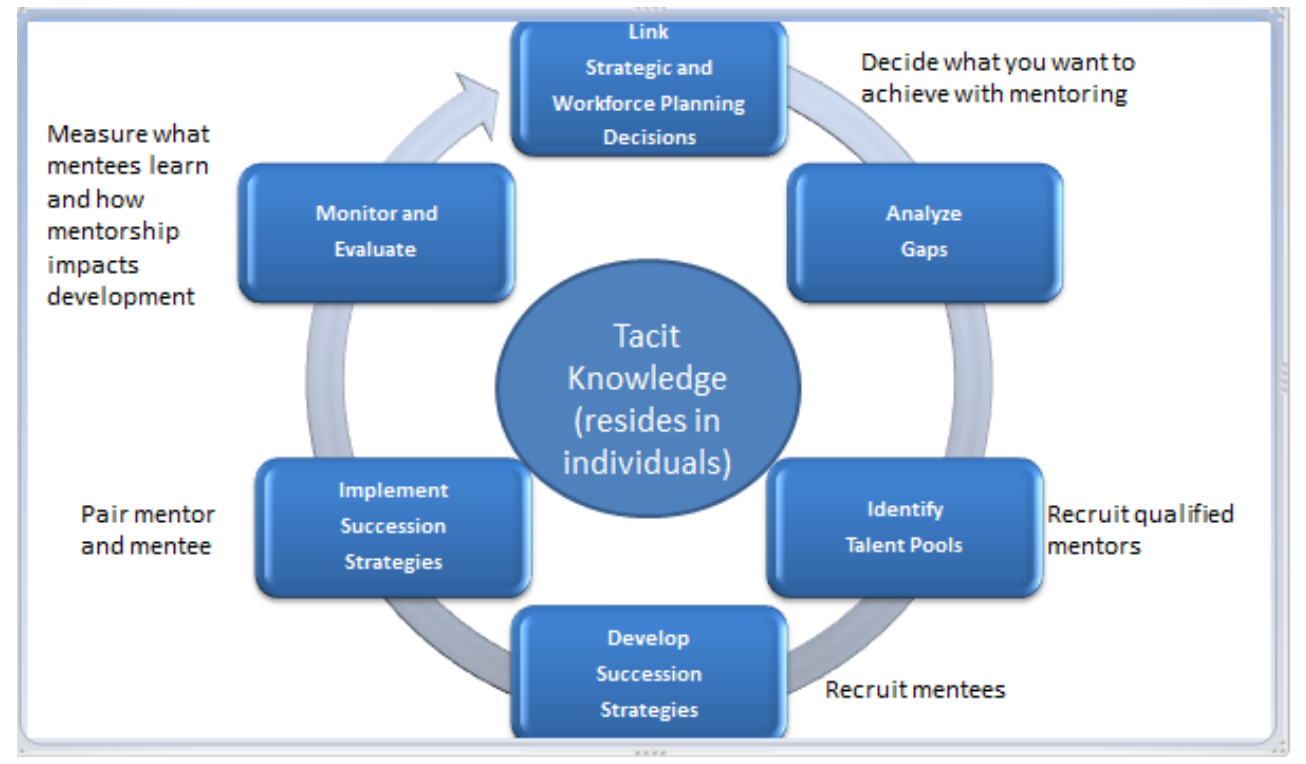

Figure 5. Tacit knowledge and mentoring in succession planning.

The American Productivity and Quality Center (APQC) (APQC, 2014) conducted a survey on how companies use mentoring to develop future experts. In the survey, $89 \%$ of respondents said their organizations use mentoring or apprenticeship to help scientific and technical employees develop their skills and competencies. Over $50 \%$ of the companies indicated that having mentors was effective.

\section{CRITICAL SKILLS}

Succession planning is a strategy where a company identifies the types of competencies that are important in fulfilling its mission and goals. Defining critical skills and competencies is the key to a good succession plan. Critical skills help facilitate the continuation of mission-critical work that enables a company to attain its goals.

The IAEA suggested a position risk factor ranking for attrition-related knowledge loss. The ranking enables a company to identify mission-critical skills and classifies employees according to their contributions and possession of tacit knowledge. The position risk factor ranges (IAEA, 2006) from 1 to 5. In light of tacit knowledge, an adapted interpretation of the IAEA ranking is shown below.

5 - Most critical, no replacement readily available, lack of documentation for tacit knowledge

4 - Critical, few available replacements, some documentation of tacit knowledge

3 - Critical, replacements available, documentation of tacit knowledge exists

2 - Not mission critical, recruits trainable in a year 
1 - Least critical, replacement through external hires

This interpretation of the IAEA ranking will be used in the next section to identify critical skills.

\subsection{CRITICAL SKILLS OF A SUBJECT MATTER EXPERT}

When identifying a subject matter expert's (SME) potential and relevant critical skills, certain aspects of the SME need to be considered: (1) Who is the SME? (2) What unique tasks, knowledge, and experience does the SME have? (3) What critical skills does the SME have?

For the purposes of this study, the critical skill sets being considered are those that apply to a nuclear facility. Specific SMEs in such a facility will be presented in the next section.

\subsection{IDENTIFYING CRITICAL SKILLS IN A NUCLEAR FACILITY}

The most common skill sets required for an employee (Casserly, December 10, 2012) include the ability to handle work challenges and solve complex problems, the ability to respond to any emergency, availability to attend required training and certification, ability to communicate and actively listen, ability to accept criticism, ability to face a difficult situation and the ability to face constant time pressure.

The IAEA estimates that it takes about 200-1000 individuals (IAEA, 2007) to operate a commercial nuclear power plant. The workforce at a nuclear power plant comes from a diverse background, including nuclear engineering, instrumentation and control, electrical engineering, mechanical engineering, radiation protection, chemistry, emergency preparedness, and safety analysis and assessment. The Nuclear Energy Institute (Nuclear Energy Institute, 2016) provided a general job description for most of these positions (https://nei.org/Careers-Education/Careers-in-the-Nuclear-Industry/Help-for-Your-JobSearch/Sample-Job-Descriptions-and-Salaries).

Critical skills for safeguards are strongly related to core capabilities. The ORISE (ORISE, 2009) study categorized the core capabilities for safeguards into three levels: facility, state-wide, and international. 
Facility-related core capabilities include:

1. Nuclear materials accounting

2. Nondestructive assay

3. Destructive assay

4. Containment technology

5. Data authentication

6. Surveillance systems

7. Design verification technology

8. Safeguards simulation \& modeling

9. Information systems

10. Location-specific environmental sampling and analysis

11. Safeguards systems approaches, design, and evaluation

12. Technology-specific proliferation risk analysis

State-wide core capabilities include:

1. Nuclear materials accounting

2. Nondestructive assay

3. Destructive Assay

4. Containment technology

5. Data authentication

6. Surveillance systems

International core capabilities include:

1. Nonproliferation regime expertise

2. Safeguards agreements and legal authorities

3. Nonproliferation/safeguards policy analysis

4. Safeguards infrastructure development

5. Safeguards education and training

\subsection{SUBJECT MATTER EXPERTS}

For illustrative purposes, in this subsection, two SMEs will be analyzed: (1) the reactor operator, and (2) the IAEA inspector. These two examples are chosen since the report deals with critical skills in nuclear facilities and in the nuclear safeguards field. 


\subsubsection{Reactor Operator}

A reactor operator, licensed by the $\mathrm{NRC}$, is responsible for operating the reactor controls in cooperation with the remainder of the shift team. Based on the job description provided by NEI (Nuclear Energy Institute, 2016), a sample table of critical skills is presented in Table 1. Sample critical skills for a reactor operator.

Table 1. Sample critical skills for a reactor operator

Knowledge and understanding of nuclear power plant mechanical and electrical systems

Knowledge and understanding of nuclear power plant technical specifications

Knowledge and understanding of government regulations

Knowledge and understanding of operations and procedures

Ability to generate creative solutions to work situations

Ability to maintain high personal standards of performance, responsibility, and professionalism

Ability to respond to a nuclear emergency

Availability to attend required training and certification

Ability to communicate with other staff

Ability to accept criticism

Ability to face a difficult situation

Ability to face constant time pressure

Critical thinking

Complex problem solving

Judgment and decision making

Active listening

Computer skills 


\subsubsection{IAEA Inspector}

An IAEA inspector (IAEA, 2014) investigates nuclear facilities to verify that they conform to established safeguard standards. Derived from the IAEA inspector's job description, a sample of critical skills for this role is presented in Table 2. Sample critical skills for an IAEA inspector.

Table 2. Sample critical skills for an IAEA inspector

Knowledge of the nuclear fuel cycle and associated facilities

Knowledge and understanding of enrichment, reprocessing

Knowledge of NDA and DA

Knowledge of fuel fabrication, nuclear trade analysis, nuclear forensics

Ability to assimilate and analyze complex situations

Ability to adapt and face unexpected situations and events

Ability to maintain high personal standards of performance, responsibility, and

professionalism

Ability to observe, look for indicators and report findings accurately

Ability to respond to a nuclear emergency

Availability to attend required training and certification

Ability to communicate effectively with people from diverse cultural background

Ability to interface with national authorities

Ability to work in different cultural settings

Ability to accept criticism

Ability to face a difficult situation

Ability to face constant time pressure

Critical thinking

Judgment and decision making

Active listening

Computer skills

\section{CRITICAL SKILLS METHODOLOGY}

\subsection{PURPOSE OF THE METHODOLOGY}

DOE's (NNSA must maintain a skilled work force, particularly in the field of international safeguards. Identifying critical skills for its workforce allows the NNSA to ensure that current and future employees possess the right skills to enable optimal performance of the agency and, by extension, ensure nuclear security. For this work, a methodology in line with the needs and strategic objectives of the NNSA was developed to identify the skills and knowledge necessary for personnel to properly carry out missioncritical functions in nuclear operations as they relate to international safeguards. The desired product will be a map of an individual's tasks, knowledge, and skills with a rating of how critical each item is to the success of the overall mission. 


\subsection{CRITICAL SKILLS}

A critical skill facilitates the successful completion of tasks in line with an organization's mission. To identify critical skills, several questions need to be posed:

- What is the organization's mission?

- What are the organization's business goals?

- What processes and procedures are currently in place?

- What critical skills are needed to be able to perform the mission and meet the goals?

\subsection{METHODOLOGY}

A six-step methodology for identifying critical skills is proposed

1. Select a nuclear facility or group of experts at a DOE national laboratory

2. Select candidates

3. Interview candidates

4. Analyze interview results

5. Validate critical skills and level of criticality

6. Assess potentially-critical skills by listing and ranking them using the IAEA position risk factor scale of $1-5$

Each of the steps above will be described, in order, in the following subsections.

\subsubsection{Select a Nuclear Facility or Expert Group of Individuals at a DOE National Laboratory}

The facility or group must be integral to DOE's mission and must have been in operation for several years. Because they serve DOE's mission, experts must have worked in the facility or group for a considerable amount of time.

\subsubsection{Select Candidates}

The manager of the facility or group will aid in identifying individuals who have the desired critical skills. Criteria could include how the loss of an employee could have a significant impact on the organization; the minimum number of employees required for operation; employee job titles and job positions; and the number of employees eligible to retire, and of these which individuals and job positions are vital to laboratory operation.

Specifically, the steps would be:

- Meet with facility or group manager and operations managers to identify individuals with critical skills in their respective areas.

- Interview operations managers to determine the individual(s) whose departure(s) would negatively impact the organization. Obtain the job titles and job descriptions for these individuals. If there are many individuals identified, and a job title is shared by more than one individual, ask the manager to categorize the job importance of those individuals based on the impact of losing them on short notice.

- Validate the names of those deemed most critical by reviewing the list with the manager. 


\subsubsection{Interview Process}

The interview process will involve a prepared questionnaire (see Appendix A) and at least two interviewers - one asking questions and the other recording the session and possibly employing a recording device. One of the interviewers should have technical know-how or familiarity with the expert's field. The questionnaire will be reviewed by the manager and then sent to the potential interviewee/expert prior to the session. The interviewee should be informed by their manager of the purpose of the interview and its importance. The potential interviewee/expert will complete the form and return it to the interviewers. Once the interviewers get a copy of the completed questionnaire, and have had a chance to digest the input, a date will be set for the follow-up, person-to-person session. The follow-up interview is to occur in a quiet place. After the interview session is over, the interviewers will provide a summary of the interview. The summary is to be vetted by the interviewed expert to ensure that no errors are made in the transcription and that any additional, pertinent information is added.

\subsubsection{Analyze Interview Results}

The analysis is designed to determine potentially critical skills. The interviewers take the notes from the interview and analyze the information to extract the critical skills for each interviewee. The interviewers, with the aid of the facility manager, then review the questionnaires and interview transcripts to compile a list of skills. A table of critical skills for each interviewee can then be compiled.

\subsubsection{Validate Critical Skills and Level of Criticality}

Validating critical skills and their level of criticality is to be performed by the manager, the interviewers, the interviewee and possibly a resident expert who is familiar with the interviewee's functions. The manager ensures that the critical skills are in line with the organization's mission. The interviewers share their analysis with the manager, the interviewee and/or operations managers to validate the criticality of the skills identified and to ascertain the level of criticality of each skill and individual. The relevant job descriptions for the interviewees would also play a crucial role in validating the critical skills. If a current job description is not available, drafting or updating a job description would be helpful. The agreed-upon level of criticality would be included in the analysis as a spreadsheet.

\subsubsection{Assess Potentially-Critical Skills}

As a final output, the assessment will feature a table of skills with a level of criticality defined for each skill. The interviewers will complete the table with other output from the interviews and provide the output to the facility or group manager and the operations managers, who can then proceed to plan for knowledge retention (KR) for those critical skills.

The output from each interview, together with the job description, will be summarized in a table with the critical skills listed first. Each skill will be ranked from 1 to 5, using IAEA's position risk factor criteria (IAEA, 2006).

As an example, the critical skills for a reactor operator have been compiled and ranked below (Table 3). The ranking is for illustrative purposes only. 
Table 3. Sample ranking of critical skills for a reactor operator

\begin{tabular}{|c|c|c|c|c|c|}
\hline Critical skill for reactor operator & 1 & 2 & 3 & 4 & 5 \\
\hline $\begin{array}{l}\text { Knowledge and understanding of nuclear power plant } \\
\text { mechanical and electrical systems }\end{array}$ & & & & & $\checkmark$ \\
\hline $\begin{array}{l}\text { Knowledge and understanding of nuclear power plant } \\
\text { technical specifications }\end{array}$ & & & & & $\checkmark$ \\
\hline Knowledge and understanding of government regulations & & & & & $\checkmark$ \\
\hline Knowledge and understanding of operations and procedures & & & & & $\sqrt{ }$ \\
\hline Ability to generate creative solutions to work situations & & & & & $\checkmark$ \\
\hline $\begin{array}{l}\text { Ability to maintain high personal standards of performance, } \\
\text { responsibility, and professionalism }\end{array}$ & & & & & $\sqrt{ }$ \\
\hline Ability to respond to a nuclear emergency & & & & & $\checkmark$ \\
\hline Availability to attend required training and certification & & & & $\checkmark$ & \\
\hline Ability to communicate with other staff & & & & $\checkmark$ & \\
\hline Ability to accept criticism & & & & $\checkmark$ & \\
\hline Ability to face a difficult situation & & & & $\checkmark$ & \\
\hline Ability to face constant time pressure & & & & $\checkmark$ & \\
\hline Critical thinking skills & & & & $\checkmark$ & \\
\hline Complex problem solving skills & & & & $\checkmark$ & \\
\hline Judgment and decision making skills & & & & $\checkmark$ & \\
\hline Active listening skills & & & $\checkmark$ & & \\
\hline Computer skills & & & $\checkmark$ & & \\
\hline
\end{tabular}

\section{CONCLUSIONS}

This study attempts to address succession planning. Particularly, a methodology to identify critical skills for technical/subject matter experts (SMEs) is proposed. The methodology involves selection of a nuclear facility, selecting the SMEs who are keys to the operation, the interview process, identification of the critical skills and assessment. There is no straight forward formula for the methodology as it depends on the needs of a nuclear facility. Each step in the methodology is subject to such an adaptation. The next step is to apply the methodology with the intent that critical skills can be identified through interviews of SMEs and subsequent analysis of respective jobs. 


\section{BIBLIOGRAPHY}

Department of Energy. (2016). 2016-2020 Strategic Human Capital Plan. Washington, DC.

National Research Council. (2012). Assuring a Future U.S.-Based Nuclear and Radiochemistry. Washington, DC: National Academies Press.

APQC. (2014). Effectiveness of a Mentoring Program. Houston, Texas: American Productivity and Quality Center.

Casserly, M. (December 10, 2012). The 10 Skills That Will Get You Hired In 2013. Forbes Magazine. Retrieved from Forbes: http://www.forbes.com/sites/meghancasserly/2012/12/10/the-10-skillsthat-will-get-you-a-job-in-2013/\#3e36ba3a664b

IAEA. (2004). The nuclear power industry's ageing workforce: Transfer of knowledge to the next generation, IAEA Tecdoc-1399. Vienna, Austria: IAEA.

IAEA. (2006). Risk Management of Knowledge Loss in Nuclear Industry Organizations IAEA-1248. Vienna, Austria.

IAEA. (2007). Considerations to Launch a Nuclear Power Programms. Vienna, Austria: IAEA.

IAEA. (2013). IAEA Department of Safeguards Long-Term R\&D Plan, 2012-2023, STR-375. Vienna, Austria: IAEA.

IAEA. (2014). Vacancy Notice No. 2014/064. Retrieved September 23, 2016, from IAEA: https://recruitment.iaea.org/vacancies/p/2014/2014_064.html

IAEA Nuclear Energy Series. (2011). Comparative Analysis of Methods and Tools for Nuclear Knowledge Preservation and Management, IAEA Pub 1494. Vienna, Austria: IAEA.

Lucas, K. (2017). http://work.chron.com/questions-functional-technical-skills-interview-28720.html. Retrieved March 28, 2017, from Houston Chronicle: http://work.chron.com/questions-functionaltechnical-skills-interview-28720.html

NEI. (2016). Careers and Education. Retrieved September 23, 2016, from Sample Job Descriptions and Salaries: http://nei.org/Careers-Education/Careers-in-the-Nuclear-Industry/Help-for-Your-JobSearch/Sample-Job-Descriptions-and-Salaries

NRC. (2012). ELECTIVE POLICY ISSUE \# 3: HUMAN RESOURCES AND KNOWLEDGE MANAGEMENT. Retrieved 2016, from NRC: http://www.nrc.gov/docs/ML1125/ML112510341.pdf

ORISE. (2009). Nuclear Nonproliferation International Safeguards Scientist and Engineer Workforce at U.S. Department of Energy National Laboratories. Oak Ridge, Tennessee.

Shaheen Dewji, S. P. (2015). Human Capital Roadmap in Safeguards and Nonproliferation Education, Training, and Knowledge Retention - Knowledge Management Strategic Plan - ORNL/TM2014/673. Oak Ridge, Tennessee: Oak Ridge National Laboratory.

Timothy Lagan, M. B.-L. (2005). Workforce and Succession Planning for Mission Critical Operations. Washington, DC.

US Office of Personnel Management. (2005). Succession Planning. Washington, DC. 


\section{APPENDIX A. TECHNICAL EXPERT INTERVIEW QUESTIONS}

These questions are derived from (IAEA, 2006) and (Lucas, 2017) and modified for the purposes of this study.

\section{TACIT KNOWLEDGE}

1. What is your job title?

2. What educational background do you have?

3. How long have you been with the organization?

4. Do you have experience as an expert in previous jobs that relates to your current job?

5. What is your major function in your current job?

6. In your current role, what unique skill sets are required? In what areas do fellow employees seek your expertise?

7. Does your workplace have a process to capture vital knowledge?

8. What available organizational resources aid you in performing your job?

9. Does your work necessitate that you to keep up with publications (e.g., open literature)?

10. Other than the general organizational requirements, do you have to attend job-specific critical training on a regular basis? How often?

11. What other roles do you have?

12. If you had to leave the organization for any circumstance, how long do you think it would take for someone to adequately assume your role?

13. In relation to the above question, what would be the timeframe for training your replacement?

14. What are the top three things you would share with someone new to this role?

\section{EXPLICIT KNOWLEDGE}

1. Does a physical library exist for documented resources?

2. Are there databases available?

\section{PROFESSIONAL ACTIVITIES}

1. Are you a member of a professional society?

2. If so, how does the membership add value to your job? 